\title{
MODEL LITERASI INFORMASI BAGI MAHASISWA BARU DI PERPUSTAKAAN UNIVERSITAS KRISTEN SATYA WACANA SALATIGA JAWA TENGAH
}

\author{
Albertoes Pramoekti Narendra \\ Program Studi S1 Perpustakaan \\ Fakultas Teknologi Informasi \\ Universitas Kristen Satya Wacana \\ Email : alberto.pramukti@uksw.edu
}

\begin{abstract}
ABSTRAK
Penelitian ini dilakukan untuk mengetahui kemampuan mahasiswa baru dalam mengenali sumber informasi dan pemanfaatan informasi khususnya di Universitas Kristen Satya Wacana melalui program literasi informasi yang dilaksanakan Perpustakaan. Metode yang digunakan dalam penelitian ini adalah deskriptif kualitatif dengan studi literatur dan dokumen yang ada. Program literasi informasi bagi mahasiswa baru dilaksanakan dalam rangka memberikan bekal pengetahuan dan pengalaman dalam cara pembelajaran di perguruan tinggi yang berbeda dengan di tingkat SMA. Hasil dari penelitian ini antara lain adalah penerapan model literasi informasi yang unsur unsurnya terdapat dalam model literasi informasi yang saat ini dikenal secara global.

Kata-kunci: literasi informasi, mahasiswa, perpustakaan UKSW, pembelajaran
\end{abstract}

\begin{abstract}
This research was conducted to determine the ability of new students to recognize information sources and use information, especially at Satya Wacana Christian University through an information literacy program implemented by the Library. The method used in this research is descriptive qualitative study of existing literature and documents. Information literacy program for new students is carried out in order to provide knowledge and experience in the way of learning in universities that are different from those at the high school level. The results of this research include the application of information literacy models whose elements are contained in information literacy models that are currently known globally.
\end{abstract}

Keywords: information literacy, students, SWCU Library, learning

\section{PENDAHULUAN}

Memasuki tingkat pendidikan yang lebih tinggi di lingkungan perguruan tinggi setiap mahasiswa akan mengalami perbedaan suasana belajar dari sebelumnya ketika di bangku sekolah menengah atas. Salah satu yang membedakan adalah cara mahasiswa menemukan dan mengolah informasi dalam rangka menyelesaikan berbagai tugas yang akan dihadapi semasa duduk di bangku perkuliahan. Di masa sekarang ini ada jutaan informasi yang tercipta setiap hari dan dalam berbagai kemasan informasi serta kemudahan dalam mengakses serta kecepatan dalam mendapatkannya. Untuk itulah setiap mahasiswa membutuhkan 
keterampilan dalam mencari dan memanfaatkan berbagai sumber-sumber informasi yang tersedia. Kemampuan itu dinamakan literasi informasi. Literasi informasi (melek informasi) menurut American Library Association (ALA) (2000) adalah satu rangkaian kemampuan individu untuk mengenali informasi saat diperlukan dan memiliki kemampuan untuk menemukan, mengevaluasi, dan menggunakan informasi tersebut secara efektif. Setiap mahasiswa memiliki perbedaan dalam memiliki kemampuan untuk memperoleh informasi dalam mencukupi kebutuhan informasinya sehingga dari perbedaan tingkat kemampuan inilah dapat diketahui seberapa baik proses menganalisis sebuah informasi yang diterima dan menjadi pengetahuan yang baru.

Perpustakaan Universitas Kristen Satya Wacana sebagai lembaga penyedia jasa dan layanan informasi bagi sivitas akademika juga memiliki tugas serta fungsi untuk melakukan pendampingan bagi seluruh sivitas akademika. Salah satu unsur sivitas akademika yang perlu didampingi adalah mahasiswa baru yang masuk setiap tahun akademik. Hal ini dilakukan dengan pertimbangan bahwa mahasiswa yang baru masuk masih belum memiliki banyak pengalaman dalam memanfaatkan berbagai sumber informasi yang disediakan di dalam Perpustakaan UKSW. Seorang yang melek informasi adalah seseorang yang mampu:

1. Mengetahui sejauh mana informasi dibutuhkan

2. Mengakses informasi yang dibutuhkan secara efektif dan efisien

3. Mengevaluasi informasi dan sumbernya secara kritis

4. Menggabungkan informasi terpilih ke dalam basis pengetahuan seseorang

5. Menggunakan informasi secara efektif untuk mencapi tujuan tertentu

6. Memhami tentang kondisi ekonomi, hukum, dan isu sosial seputar penggunaan informasi dan menggunakan isu sosial di seputar informasi dan menggunakan informasi dan akses serta menggunakan informasi secara legal dan etis.

Dari latar belakang tersebut maka tulisan ini akan difokuskan kepada Model Literasi Informasi Mahasiswa Baru di Perpustakaan UKSW dan manfaat yang diperoleh setelah mengikuti kegiatan tersebut.

\section{Landasan Teori}

Istilah "information literacy" pertama kali dikemukakan oleh Paul Zurkowski yang mengatakan orang yang literat informasi adalah orang-orang yang terlatih dalam aplikasi sumberdaya dalam pekerjaanna (Behrens,1994). Setelah ittu keluar definisi LI oleh ANZIL (Australian and New Kesepakatan definisi LI baru tercapai tahun 2005 tatkala IFLA, UNESCO dan National Forum for Information Literacy (NFIL) menaja pertemuan tingkat tinggi di Bibliotheca Alexandriana di Alexandria, Mesir. Sebagai hasil pertemuan muncullah definisi LI sebagai berikut : Information literacy encompasses knowledge of one's information concerns and needs, and the ability to identify, locate, evaluate, organize, and effectively create, use and communicate information to address issues or problems at hand; it 
is a prerequisite for participating effectively in the Information Society, and is part of the basic human right of life - long learning. (Sulistiyo Basuki)

Menurut Bundy dalam Hasugian (2009:200) "Literasi informasi adalah seperangkat keterampilan yang diperlukan untuk mencari, menganalisis dan memanfaatkan informasi". Senada dengan definisi tersebut dalam laporan penelitian America Library Association's Presidental Commite on Information Literacy (1989:1) dikatakan bahwa "information literacy is a set of abilities requiring individuals to recognize when information is needed and have the ability to locate, evaluate, and use effectivelly the needeed information".

Dari pemahaman tersebut maka penulis dapat menarik satu pemahaman bahwa literasi informasi merupakan sebuah kemampuan dasar yang harus dimiliki oleh seseorang dan dengan kemampuan dasar itu seseorang mampu untuk mengembangkan dirinya melalui berbagai informasi dan pengetahuan yang jauh lebih baik dari segi sumber informasi, data, pencipta dan juga konten informasi itu sendiri.

\section{Model Literasi Informasi}

Adanya model literasi informasi memberikan kemungkinan kepada kita untuk mengenali berbagai unsur dan komponen serta memberikan petunjuk keterkaitan antar komponen. Dengan adanya model memberikan manfaatkan untuk menjelaskan terkait dengan tujuan dan maksud dengan literasi informasi. Dari hal tersebut kemudian kita dapat memusatkan pada bagian yang lebih spesifik atau juga model secara menyeluruh.

Tabel 1. Perbandingan Model Literasi Informasi

\begin{tabular}{|c|c|c|c|}
\hline $\begin{array}{l}\text { Nama } \\
\text { Model } \\
\end{array}$ & Deskripsi & Skema & Tahapan \\
\hline The Big6 & $\begin{array}{l}\text { Dikembangka } \\
\text { n di Amerika } \\
\text { Serikat) oleh } \\
\text { Mike } \\
\text { Eisdenberg } \\
\text { dan Bob } \\
\text { Berkowitz } \\
\text { untuk } \\
\text { Sekolah }\end{array}$ & $\begin{array}{l}\text { The Big } 6 \\
\text { Step 6: } \\
\text { Evaluation }\end{array}$ & \begin{tabular}{|l} 
1. \\
Definisi Tugas (Task \\
Definition) \\
Strategi pencarian \\
informasi (Information \\
Seeking Strategies) \\
3. $\begin{array}{l}\text { Lokasi dan Akses } \\
\text { (Location and Access) }\end{array}$ \\
4. $\begin{array}{l}\text { Menggunakan informasi } \\
\text { (Use of Information) }\end{array}$ \\
5. Sintesis (Synthesis) \\
6. Evaluasi (Evaluation)
\end{tabular} \\
\hline
\end{tabular}




\begin{tabular}{|c|c|c|c|}
\hline $\begin{array}{l}\text { The } \\
\text { Seven } \\
\text { Pillars of } \\
\text { Informatio } \\
\text { Literacy }\end{array}$ & $\begin{array}{l}\text { Dikembangka } \\
\mathrm{n} \text { oleh } \\
\text { SCONUL } \\
\text { (Standing } \\
\text { Conference } \\
\text { of National } \\
\text { and } \\
\text { University } \\
\text { Libraries) }\end{array}$ & 59 C C NI L L & $\begin{array}{l}\text { 1. Identify - Paham } \\
\text { kebutuhan informasi } \\
\text { 2. Scope - Tentukan jenis } \\
\text { informasi, karakteristik, } \\
\text { tantangan } \\
\text { 3. Plan - Tentukan strategi } \\
\text { pencarian, kata kunci } \\
\text { 4. Gather - Lakukan } \\
\text { pencarian, akses } \\
\text { informasi } \\
\text { 5. Evaluate - Relevansi, } \\
\text { akurasi, pembandingan, } \\
\text { 6. Manage - Kelola } \\
\text { informasi, mengutip, } \\
\text { susun bibliografi, tahu } \\
\text { etika gunakan informasi } \\
\text { 7. Present - Menyusun } \\
\text { produk informasi dalam } \\
\text { bentuk yang tepat dan } \\
\text { menyajikan }\end{array}$ \\
\hline
\end{tabular}




\begin{tabular}{|c|c|c|c|}
\hline Nama Model & Deskripsi & Skema & Tahapan \\
\hline $\begin{array}{l}\text { Empowering } \\
\text { Eight }(E 8)\end{array}$ & $\begin{array}{l}\text { Dikembangkan } \\
\text { pada International } \\
\text { Workshop on } \\
\text { Information Skills } \\
\text { for Learning } \\
\text { IFLA/ALP dan } \\
\text { NILIS di } \\
\text { University of } \\
\text { Colombo, Sri } \\
\text { Lanka. }\end{array}$ & AFrY & $\begin{array}{l}\text { 1. Identifikasi masalah } \\
\text { (Identify) } \\
\text { 2. menemukan sumber } \\
\text { informasi (explore) } \\
\text { 3. Memilih yang paling } \\
\text { tepat (Select) } \\
\text { 4. Mengelola informasi } \\
\text { yang ada (Organize) } \\
\text { 5. menciptakan } \\
\text { pengetahuan baru yang } \\
\text { ditemukan sebagai } \\
\text { jawaban masalah } \\
\text { (Create) } \\
\text { 6. Menyajikan (Present) } \\
\text { 7. Menikai (Assess) } \\
\text { 8. menggunakan } \\
\text { pengetahuan baru } \\
\text { tersebut (Apply) }\end{array}$ \\
\hline $\begin{array}{l}\text { Bruce's } \\
\text { Seven faces } \\
\text { of } \\
\text { information } \\
\text { literacy }\end{array}$ & & 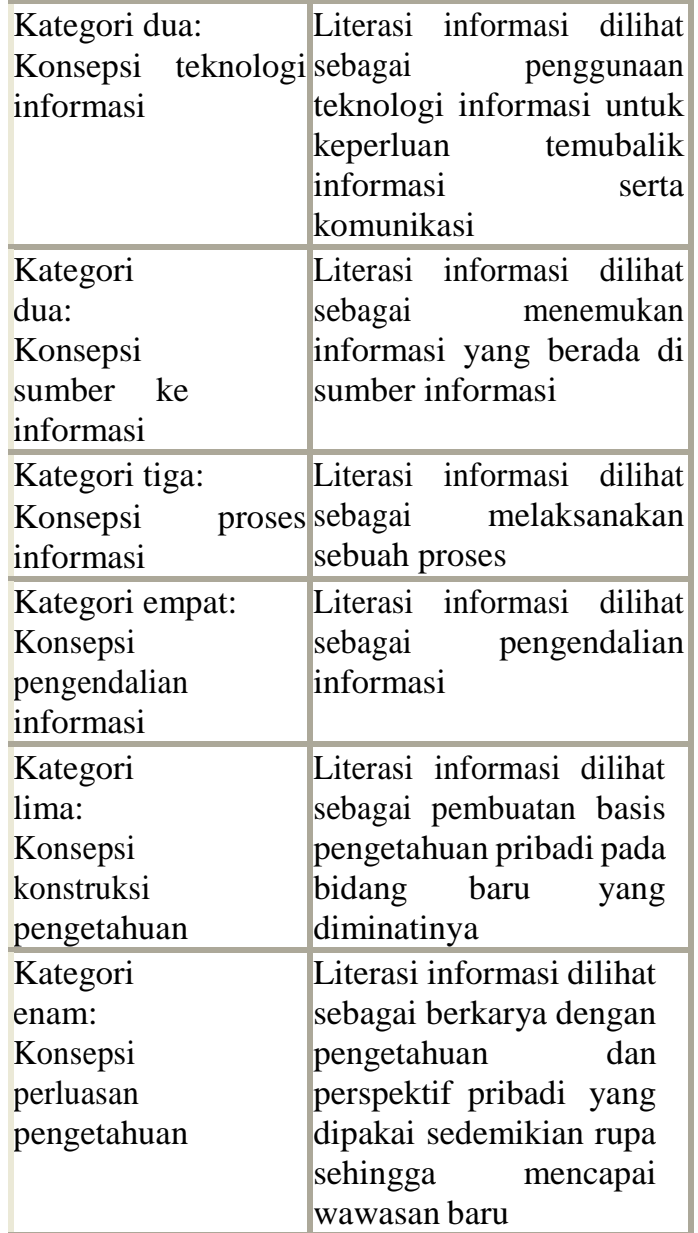 & \\
\hline
\end{tabular}




\begin{tabular}{|l|l|l|}
\hline $\begin{array}{l}\text { Kategori } \\
\text { tujuh:Konsepsi } \\
\text { kearifan }\end{array}$ & $\begin{array}{l}\text { Literasi informasi dilihat } \\
\text { sebagai } \\
\text { menggunakan informasi } \\
\text { secara bijak bagi } \\
\text { kemudaratan orang lain }\end{array}$
\end{tabular} \mid

\begin{tabular}{|c|c|c|c|c|}
\hline Nama Model & Deskripsi & Skema & & Tahapan \\
\hline $\begin{array}{l}\text { McKinsey } \\
\text { Model }\end{array}$ & & 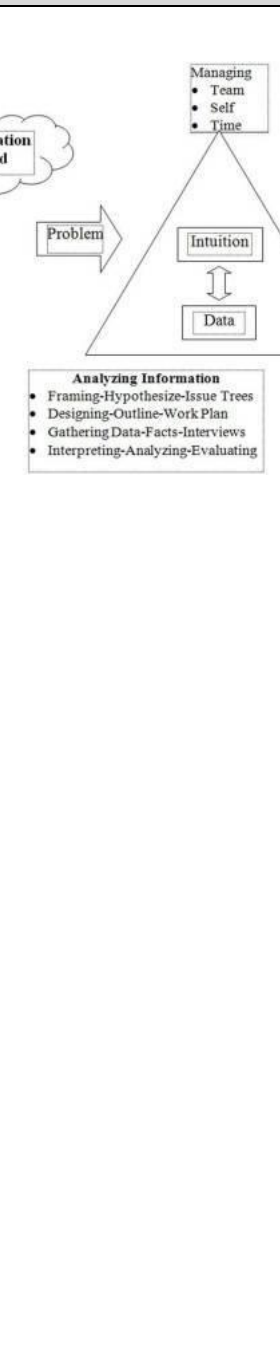 & 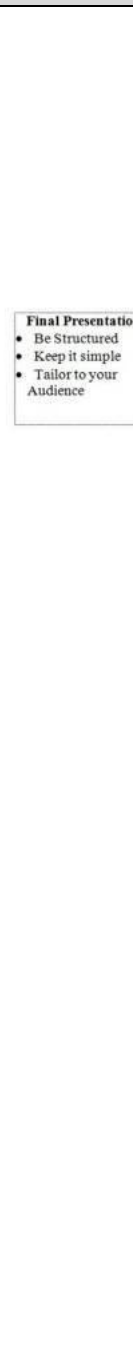 & 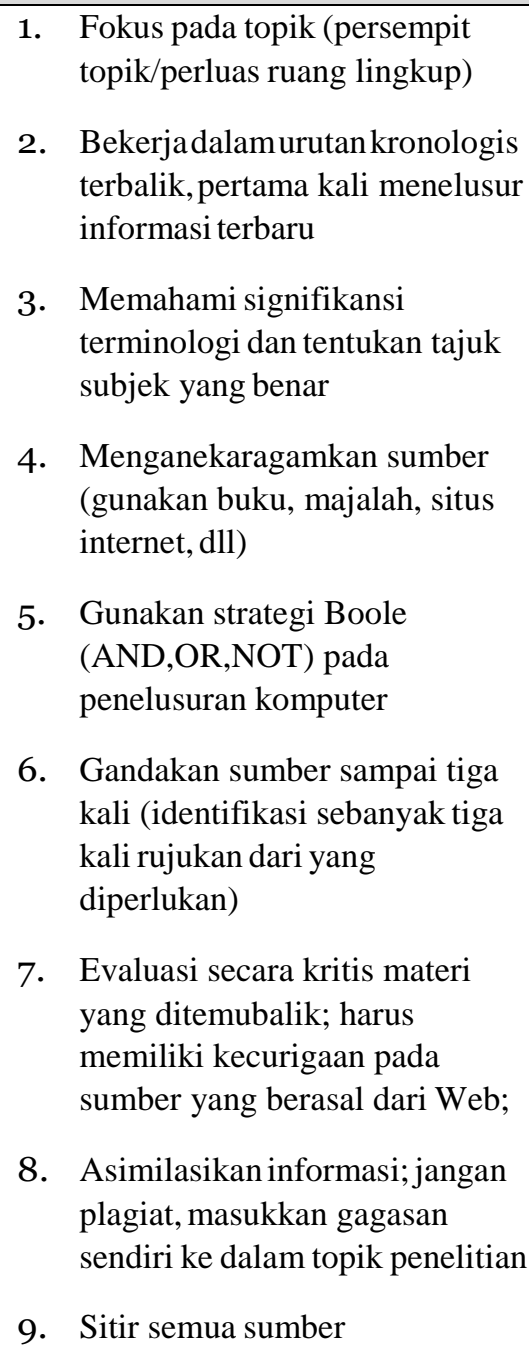 \\
\hline British Model & $\begin{array}{l}\text { Dikembangkan } \\
1981 \text { oleh } \\
\text { Michael } \\
\text { Marland dalam } \\
\text { bukunya } \\
\text { Information } \\
\text { Skills in the } \\
\text { Secondary } \\
\text { Curriculum }\end{array}$ & & & $\begin{array}{l}\text { 1. } \begin{array}{l}\text { Memformulasikan dan } \\
\text { menganalisa kebutuhan }\end{array} \\
\text { 2. Mengidentifikasi dan } \\
\text { memeriksa sumber-sumber } \\
\text { informasi } \\
\text { 3. Menelusur dan } \\
\text { menemukan sumber-sumber } \\
\text { individu }\end{array}$ \\
\hline
\end{tabular}




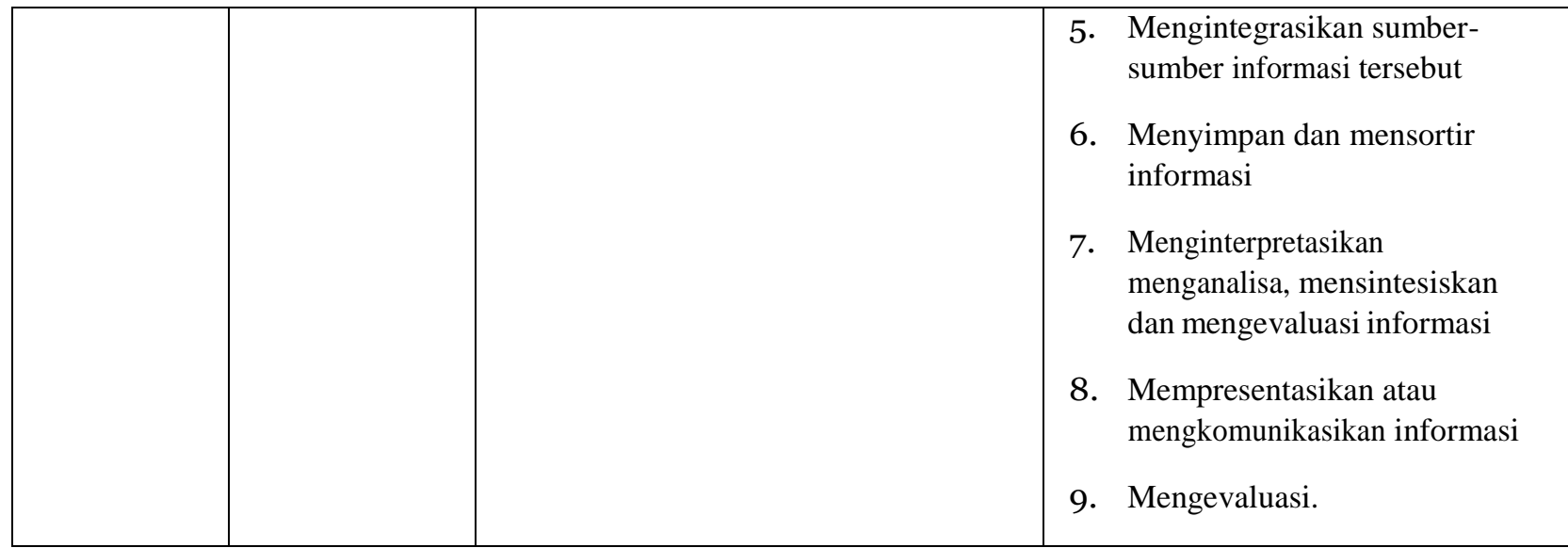

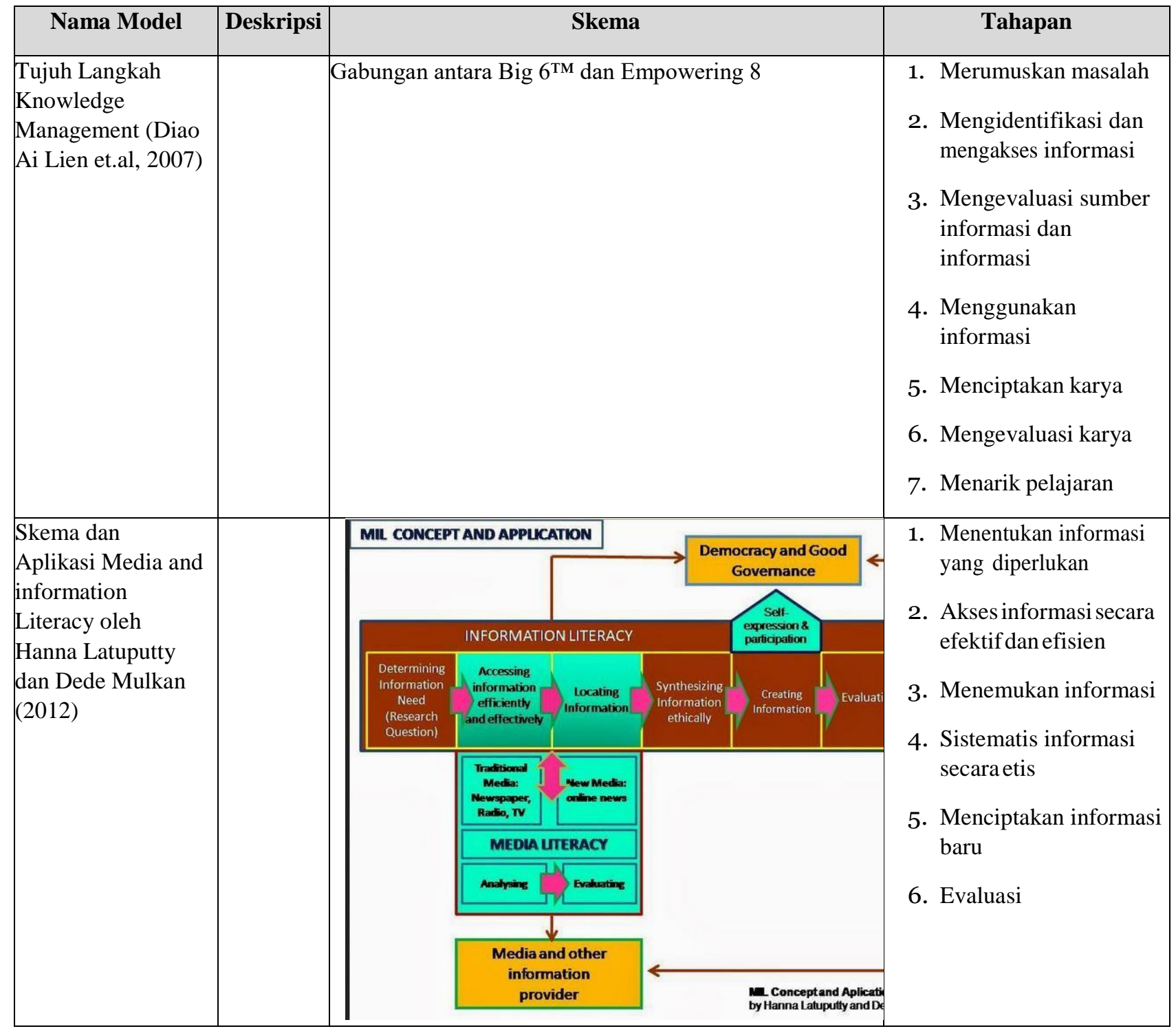

Sumber: Data yang diolah (Sulistyo-Basuki, 2012; Bruce, 1997; George, 2015) 


\section{METODE PENELITIAN}

Penelitian kemampuan mahasiswa dalam literasi informasi pada sumber informasi di Perpustakaan UKSW menggunakan metode pendekatan deskriptif kualitatif dengan kategori studi kasus. Metode penentuan informan yang penulis pakai adalah purposive sampling. Purposive sampling adalah teknik pengambilan sampel dengan pertimbangan tertentu (Sugiyono,2009:218). Sampel diambil secara purposive dengan maksud tidak harus mewakili seluruh populasi, sample yang diambil memiliki pengetahuan yang cukup serta mampu menjelaskan keadaan sebenarnya tentang obyek penelitian. Dengan menggunakan purposive sampling, diharapkan kriteria sampel yang diperoleh benar-benar sesuai dengan penelitian yang akan dilakukan.

Kriteria informannya adalah mahasiswa baru yang mengambil disiplin ilmu non eksak UKSW. Peneliti menentukan informan berdasarkan arahan dari pustakawan UKSW. Yang menjadi informan dalam penelitian ini adalah mahasiswa baru UKSW. Dalam penelitian ini digunakan teknik pengumpulan data observasi, wawancara dan dokumentasi.

\section{HASIL DAN PEMBAHASAN}

\section{Implementasi Literasi Informasi di Perpustakaan UKSW}

Pelaksanaan kegiatan literasi informasi di Perpustakaan UKSW meliputi beberapa kegiatan sebagai berikut:

1. Pengenalan Perpustakaan Notohamidjojo di dalamnya berisi tentang materi : penelusuran informasi melalui Web OPAC, dan Pengenalan Fasilitas dan layanan Perpustakaan.

2. Skimming dan Scanning meliputi yaitu: Intro membaca pribadi, latihan scanning, latihan skimming,

3. Parafrasa dan Meringkas

Kegiatan tersebut dilaksanakan khususnya bagi mahasiswa yang baru masuk ke UKSW.

\section{Komparasi dalam Model Literasi Informasi}

Dari materi yang menjadi bahan kegiatan literasi informasi bagi mahasiswa baru tersebut maka penulis dapat melakukan analisis bahwa kegiatan literasi informasi yang dilakukan merupakan salah satu konsep yang pada akhirnya akan memberikan kontribusi bagi pembelajaran literasi informasi tahap selanjutnya.

ACRL telah mengeluarkan lima standar literasi informasi dalam dunia perguruan tinggi dan kelima standar tersebut memiliki 20 indikator. Standar literasi ini berisi daftar sejumlah kemampuan yang digunakan dalam menentukan kemampuan seseorang dalam memahami informasi. Dalam standar ini terdapat cara bagaimana mahasiswa dapat berinteraksi dengan informasi. Standar ini juga digunakan oleh fakultas, pustakawan dan staff lainnya dalam mengembangkan metode untuk mengukur pembelajaran mahasiswa. Mengacu pada Standar literasi informasi ACRL (2000:8) tersebut yaitu: 
1. Mahasiswa yang literat informasi mampu menentukan jenis dan sifat informasi yang dibutuhkan.

1) Mahasiswa mendefinisikan dan menyampaikan kebutuhan informasinya.

2) Mahasiswa mengidentifikasi berbagai jenis dan bentuk sumber informasi yang potensial.

3) Mahasiswa mempertimbangkan biaya dan keuntungan yang diperoleh dari informasi yang dibutuhkan.

4) Mahasiswa mengevaluasi kembali sifat dan batasan informasi yang dibutuhkan.

2. Mahasiswa yang literat informasi mengakses kebutuhan informasi secara efektif dan efisien.

1) Mahasiswa memilih metode penelitian dan sistem temu kembali informasi yang paling tepat untuk mengakses informasi yang dibutuhkan.

2) Mahasiswa membangun dan menerapkan strategi penelusuran yang efektif

3) Mahasiswa melakukan sistem temu kembali secara online atau pribadi dengan menggunakan berbagai metode.

4) Mahasiswa memperbaiki strategi penelusuran jika diperlukan

5) Mahasiswa mengutip, mencatat dan mengolah informasi dan sumbersumbernya.

3. Mahasiswa yang literat mengevaluasi informasi dan sumber-sumber secara kritis dan menjadikan informasi yang dipilih sebagai dasar pengetahuan.

1) Meringkas ide utama yang dikutip dari informasi yang dikumpulkan.

2) Mahasiswa menentukan dan menerapkan kriteria awal untuk mengevaluasi informasi dan sumber-sumbernya.

3) Mahasiswa mampu mensintesis ide utama untuk membangun konsep baru.

4) Mahasiswa membandingkan pengetahuan baru dengan pengetahuan lama untuk menentukan nilah tambah, kontradiksi, atau karakteristik informasi unik lainnya dari informasi.

5) Mahasiswa menentukan apakah pengetahuan baru memberi dampak terhadap sistem nilai individu dan mengambil langkah-langkah untuk menyatukan perbedaan.

6) Mahasiswa menentukan bila query perlu direvisi.

4. Mahasiswa yang literat menggunakan dan mengkomunikasikan informasi dengan efektif dan efisien.

1) Mahasiswa menerapkan informasi baru dan yang lama untuk merencanakan dan menciptakan hasil.

2) Mahasiswa merevisi proses pengembangan untuk hasil.

3) Mahasiswa mengkomunikasikan hasil secara efektif kepada orang lain.

5. Mahasiswa yang literat informasi memahami isu ekonomi, hukum dan sosial sekitar penggunaan dan pengaksesan informasi secara etis dan hukum.

1) Mahasiswa memahami isu-isu ekonomi, hukum dan aspek sosial mengenai informasi dan teknologi informasi. 
2) Mahasiswa mematuhi hukum, peraturan, kebijakan intitusi, dan etika yang berhubungan dengan pengaksesan dan penggunaan sumber informasi.

3) Mahasiswa mengetahui penggunaan sumber-sumber informasi dalam mengkomunikasikan informasi.

\section{Diskusi}

Berdasarkan dari hasil studi literatur dan dokumentasi yang ada maka beberapa hal analisis penulis diskusikan sebagai berikut :

1. Perpustakaan UKSW melaksanakan program literasi informasi bagi mahasiswa baru dalam rangka memperkenalkan perpustakaan baik secara fisik maupun konten yang dimiliki untuk dimanfaatkan sebagai pemenuhan kebutuhan informasi mahasiswa.

2. Penulis menganalisis bahwa model kegiatan literasi informasi yang dikembangkan mengarah pada model The Big6. Model ini meliputi aktivitas sebagai berikut :

1) Definisi Tugas (TaskDefinition)

2) Strategi pencarian informasi (Information Seeking Strategies)

3) Lokasi dan Akses (Location and Access)

4) Menggunakan informasi (Use of Information)

5) Sintesis (Synthesis )

6) Evaluasi (Evaluation)

3. Di dalam langkah definisi tugas, mahasiswa diarahkan untuk memahami berbagai tugas sebagai mahasiswa dalam kerangka akademik misalnya mencari sumber belajar, mencari bahan untuk mendukung materi kuliah, menyusun artikel ilmiah, melakukan presentasi hasil penulisan artikel ilmiah.

4. Di dalam langkah tahap Strategi Pencarian Informasi mahasiswa diarahkan untuk mengenal berbagai strategi pencarian sumber informasi baik tercetak maupun on line. Menggunakan kata kunci atau subyek, menggunakan pendekatan penulis buku, maupun juga menggunakan operasi Boolean Logic dan serta mengenal taksonomi yang lain. Juga diperkenalkan memanfaatkan OPAC yang dimiliki oleh Perpustakaan dan langkah penelusuran informasi. Mengetahui lokasi dan dan akses terhadap informasi yang ditemukan dengan menggunakan nomor klasifikasi DDC.

5. Menggunakan informasi : para mahasiswa diperkenalkan dengan langkah pemanfaatan informasi. Mulai dari kemampuan membaca kritis teks secara utuh (scanning dan skimming) dan menyusun pertanyaan dan menjawab pertanyaan tesebut. Diharapkan dengan adanya latihan dari yang paling sederhana mahasiswa memiliki pemahaman yang semakin baik mengenai fungsi membaca secara lengkap, utuh dan memahami makna dari bacaan yang dihadapinya. Kemampuan akhir minimal yang diharapkan yaitu mahasiswa mampu untuk mengetahui kata kunci atau konsep utama dari bacaan yang dibaca. Untuk mengenali topik bacaan. Dari aktivitas tersebut dapat juga diperoleh manfaat yaitu : bagaiamana pendapat orang dalam tulisan yang 
ditulisnya, mahasiswa semakin memahami organisasi kepenulisan, mahasiswa mengetahui bagian penting yang dibutuhkan dengan tidak harus membaca keseluruhan, untuk menyegarkan fikiran terhadap teks yang pernah dibaca.

6. Sintesis : dalam tahap ini secara sederhana mahasiswa berlatih menyusun daftar pertanyaan dari bacaan yang telah diselesaikan.

7. Evaluasi : mengingat keterbatasan waktu dalam program literasi informasi ini, tahap evaluasi masih perlu dikembangkan. Evaluasi yang dilakukan masih sebatas mengenai penyajian kegiatan.

\section{SIMPULAN}

Berbagai model program literasi informasi dapat diterapkan dalam berbagai kebutuhan pengguna, sehingga perpustakaan dapat melakukan uji coba terhadap berbagai model untuk mengetahui nilai efektivitas dan efisiensinya. Program Literasi informasi bagi mahasiswa baru di Perpustakaan UKSW merupakan upaya untuk membekali kemampuan mahasiswa menelusur dan memanfaatkan sumber informasi dengan benar. Kemampuan akhir yang diharapkan antara lain mahasiswa mampu memanfaatkan fasilitas yang ada di perpustakaan, mampu menelusur informasi, mampu membaca dan menetapkan topic bacaan dan menyusun pertanyaan. Program literasi informasi Perpustakaan UKSW ke depan perlu disusun dalam jenjang jenjang tertentu. Mulai dari tingkat dasar hingga pada kebutuhan mahasiswa baik S1 hingga S3 saat menyusun tugas akhir mengingat kebutuhan dari berbagai tingkatan tersebut berlainan.

\section{Referensi:}

American Library Association.(2000). Information Literacy Competency Standards for Higher Education. Diakses dari https://alair.ala.org/bitstream/handle/11213/7668/ACRL\%20Information\%20 Literacy\%20Competency\%20Standards\%20for\%20Higher\%20Education.pdf ?sequence $=1 \&$ is Allowed $=y$

Bruce, C. (s.a.). Seven Faces of information literacy in higher education. Diakses dari http://www.christinebruce.com.au/informed-learning/seven-faces-ofinformation-literacy-in-higher-education/

Doyle, Christina S. (1994) Information Literacy in an Information Society: A Concept for the Information Age. Diakses dari https://files.eric.ed.gov/fulltext/ED372763.pdf

Guidelines On Information Literacy For Lifelong Learning. Diakses dari http://www.ifla.org/files/assets/information-literacy/publications/iflaguidelinesen.pdf

Nur Cahyati (2016). Panduan Program literasi informasi perpustakaan. file:///D:/UNUD\%20PANDUANPROGRAMLI_UNISA_23112016.pdf 
SCONUL. (2011). The SCONUL Seven Pillars of Information Literacy Core Model For Higher Education. Diakses dari https://www.sconul.ac.uk/sites/default/files/documents/coremodel.pdf

Setiawan, Candra Pratama (2017). Modul pelatihan literasi informasi. Surabaya : UK Petra.

Sugiyono. (2009). Metode Penelitian Kuantitatif, Kualitatif dan R\&D. Bandung: Alfabeta.

Sulistyo-Basuki. (2010). Metode Penelitian. Jakarta: Penaku . (2013). Literasi Informasi dan Literasi Digital, Diakses dari https://sulistyobasuki.wordpress.com/2013/03/25/literasi-informasidan-literasi-digital/

Yusuf Dzul Ikram Al Hamdy (2012). Kemampuan literasi informasi mahasiswa pada layanan American Corner di UPT Perpustakaan IAIN Walisongo Semarang menurut ASSOCIATION OF COLLEGE AND RESEARCH LIBRARIES Diakses dari https://ejournal3.undip.ac.id/index.php/jip/article/view/733 